\title{
FAKTOR - FAKTOR YANG MEMPENGARUHI KEPATUHAN \\ KUNJUNGAN IBU KE POSYANDU BALITA \\ DI DESA MENTUDA KECAMATAN LINGGA \\ TAHUN 2020
}

\author{
Fauzi \\ zifauzi565@gmail.com \\ Program Studi Sarjana Keperawatan, STIKES Awal Bros
}

\begin{abstract}
ABSTRAK
Posyandu merupakan salah satu Upaya Kesehatan Berbasis Masyarakat yang dikelola sebagai penyelenggara pembangunan kesehatan dalam memperoleh pelayanan kesehatan dasar bagi masyarakat. Pemantauan pertumbuhan dan perkembangan balita secara berkesinambungan dapat menurunkan prevalensi angka gizi kurang bahkan gizi buruk, selain itu melalui posyandu dapat diketahui ada tidaknya gangguan pemenuhan kebutuhan gizi secara dini. Penelitian ini bertujuan untuk mengetahui faktor - faktor apa saja yang dapat mempengaruhi kepatuhan kunjungan ibu balita ke posyandu balita di Desa Mentuda Kecamatan Lingga tahun 2020, dengan desain cros section dan populasi dalam penelitian ini adalah semua ibu yang mempunyai anak balita berjumlah 53 orang, sumber data primer menggunakan kuesioner dan dianalisis menggunakan sperman rho. Hasil analisis yang diperoleh dari pengolahan data menggunakan uji Spearmen Rho menunjukkan bahwa tidak ada hubungan antara pengetahuan / pendidikan dengan kepatuhan kunjungan posyandu nilai $\rho$ value $=0.791$, tidak ada hubungan antara motivasi ibu dengan kepatuhan kunjungan posyandu dengan nilai $\rho$ value $=0.609$, tidak ada hubungan antara dukungan keluarga dengan kepatuhan kunjungan posyandu dengan nilai $\rho$ value $=0,590$.
\end{abstract}

\section{PENDAHULUAN}

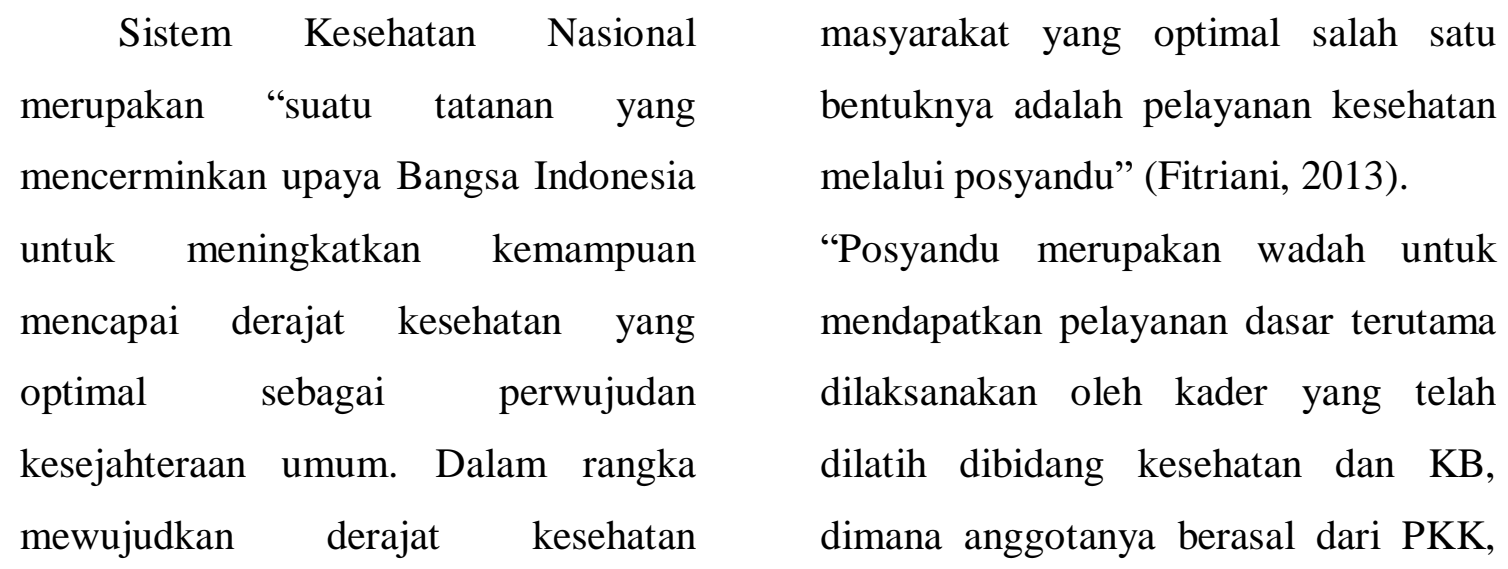


tokoh masyarakat dan pemudi. Kader kesehatan merupakan perwujudan peran serta aktif masyarakat dalam pelayanan terpadu, dengan adanya kader yang dipilih oleh masyarakat, kegiatan diprioritaskan pada lima program dan mendapat bantuan dari petugas kesehatan terutama pada kegiatan yang mereka tidak kompeten memberikannya" (Yulianti Hayya, 2012).

Program posyandu dilaksanakan untuk "kepentingan masyarakat, maka diharapkan masyarakat sendiri yang aktif membentuk, menyelenggarakan, memanfaatkan dan mengembangkan posyandu sebaik-baiknya.Kelangsungan posyandu tergantung dari partisipasi masyarakat itu sendiri. Adapun penyelenggara posyandu adalah kaderkader dan ibu-ibu PKK dari desa tersebut" (Lusi Giovani, 2013).

Balita merupakan "golongan yang rentan terhadap masalah kesehatan. Kesehatan balita pada hakikatnya adalah masalah kesehatan masyarakat yang penanggulangannya tidak dapat dilakukan secara medis dan pelayanan kesehatan saja. Gangguan kesehatan yang terjadi pada balita dipengaruhi pertumbuhan dan perkembangan baik pada masa balita maupun masa berikutnya. Upaya untuk memantau pertumbuhan dan perkembangan balita salah satunya adalah dengan posyandu".

"Kunjungan balita di posyandu berkaitan dengan peran ibu sebagai seorang yang paling bertanggung jawab terhadap kesehatan balitanya, karena balita sangat bergantung dengan ibunya, kunjungan ibu dengan membawa balita ke posyandu karena adanya motif tertentu misalnya agar anaknya mendapatkan pelayanan kesehatan yang maksimal. Untuk itu, motivasi ibu dalam pemanfaatan posyandu balita mempunyai andil yang besar dalam meningkatkan kesehatan balita" (Uphoff, 2012).

"Salah satu indikasi pemanfaatan pelayanan kesehatan oleh masyarakat adalah kepatuhan kedatangan masyarakat ke pusat pelayanan tersebut yang dalam hal ini spesifik kepada pemanfaatan pelayanan posyandu yaitu kepatuhan anak datang ke posyandu atau kepatuhan orang tua membawa anaknya ke posyandu yang dapat dilihat dari perbandingan antara jumlah anak yang ditimbang dibandingkan jumlah 
semua balita yang ada diwilayah tersebut atau D/S" (Kemenkes RI, 2011).

"Beberapa dampak yang dialami balita, bila ibu balita tidak patuh dalam kegiatan posyandu antara lain adalah tidak mendapatkan penyuluhan kesehatan tentang pertumbuhan balita yang normal, tidak mendapatkan vitamin A untuk kesehatan mata balita dan ibu tidak mendapatkan pemberian dan penyuluhan tentang makanan tambahan (PMT). Dengan aktif dalam kegiatan posyandu ibu balita dapat memantau tumbuh kembang balitanya" (Kemenkes RI, 2016).

Di posyandu desa Mentuda kegiatan posyandu dilakukan tiap bulan meliputi pemeriksaan Kesehatan Ibu dan Anak, kegiatan ini dilakukan bidan desa yang bertugas di desa tersebut, pemeriksaan kesehatan bayi dan balita ini dilakukan petugas kesehatan dan dibantu kader yang sudah ditunjuk sebanyak 5 orang, pemberian vitamin A dilakukan 2 kali dalam setahun yaitu bulan Februari dan Agustus, Pemberian Obat Cacing Massal dilakukan 2 kali dalam setahun, pemberian imunisasi dasar kepada bayi umur 0 sampai 9 bulan, dalam kegiatan imunisasi untuk mencapai target maka petugas kesehatan harus melakukan sweeping kerumah-rumah karena ibu bayi jarang mau membawa anaknya ke posyandu. Sedangkan pelaksanaan penimbangan tidak mungkin petugas harus datang sweeping kerumah-rumah dengan membawa timbangan dal peralatan lainnya. ( posyandu Mentuda)

"Hasil dari wawancara dengan beberapa ibu balita di Posyandu Desa Mentuda ternyata juga masih ada ibu yang tidak membawa anak mereka ke posyandu dengan alasan sampai ke posyandu hanya ditimbang, tidak ada manfaat sehingga membuang-buang waktu, kadang ibu lupa jadwal posyandu dan tak ada keluarga yang mengingatkan, ibu juga mengatakan kadang-kadang anaknya tidur pas waktu penimbangan dan kasian apabila dibangunkan".

Berdasarkan hasil data persentase kegiatan posyandu di desa Mentuda dari tahun 2018 dan 2019 yang masih jauh dari target pemerintah terhadap cakupan yang sudah ditetapkan dan fenomena ibu bayi dan balita dilapangan, maka peneliti tertarik untuk melakukan penelitian dengan judul “ Faktor - 
Faktor Yang Mempengaruhi Kepatuhan Kunjungan Ibu Balita Ke Posyandu Balita Di Desa Mentuda Kecamatan Lingga Tahun 2020”.

\section{METODOLOGI PENELITIAN}

Penelitian ini menggunakan "pendekatan kuantitatif observasional dengan desain penelitian cross sectional (potong lintang), dimana semua variabel baik variabel independen maupun dependen diteliti dalam satu waktu, subjek di amati sekali saja dalam satu waktu selama penelitian berlangsung sehingga tidak menggambarkan hubungan sebab akibat yaitu Faktor Faktor Yang Mempengaruhi Kepatuhan Kunjungan Ibu Ke Posyandu Balita Di Desa Mentuda Kecamatan Lingga Tahun 2020. Sampel dalam penelitian ini adalah sebanyak 53 orang dengan menggunakan metode total sampling. Data yang diperoleh, dianalisis dengan menggunakan uji statistik spearman rho".

\section{HASIL PENELITIAN}

Tabel 1.1 Distribusi Responden berdasarkan faktor pengetahuan ibu

\begin{tabular}{llcc}
\hline $\mathbf{N}$ & Pengetahuan & Frekuensi & $\%$ \\
\hline 1 & Baik & 16 & 30.2 \\
& & & \\
2 & Kurang & 37 & 69.8 \\
\hline \multicolumn{2}{l}{ Total } & 53 & 100 \\
\hline
\end{tabular}

Berdasarkan table 1.1 diatas terlihat bahwa "responden yang memiliki pengetahuan/ pendidikan yang Baik berjumlah 16 orang (30.2\%), responden yang memiliki pengetahuan/ pendidikan memiliki pengetahuan kurang berjumla h 37 orang $(69.8 \%) "$.

Tabel 1.2 Distribusi Responden berdasarkan faktor motivasi ibu

\begin{tabular}{llcc}
\hline No & $\begin{array}{c}\text { Motivasi } \\
\text { Ibu }\end{array}$ & Frekuensi & $\%$ \\
\hline 1 & Baik & 14 & 26.4 \\
2 & Kurang & 39 & 73,6 \\
\hline \multicolumn{2}{l}{ Total } & 53 & 100 \\
\hline
\end{tabular}

Berdasarkan table 1.2 diatas terlihat bahwa "responden yang memiliki motivasi ibu yang Baik berjumlah 14 orang $(26,4 \%)$ dan 
respoden yang memiliki motivasi ibu yang kurang berjumlah 39 orang $(73,6 \%)$ ".

Tabel 1.3 Distribusi Responden berdasarkan faktor dukungan keluarga

\begin{tabular}{cccc}
\hline No & $\begin{array}{c}\text { Dukungan } \\
\text { Keluarga }\end{array}$ & Frekuensi & \% \\
\hline $1 \quad$ Baik & 11 & 20,8 \\
2 & Kurang & 42 & 79,2 \\
\hline \multicolumn{2}{l}{ Total } & 53 & 100 \\
\hline
\end{tabular}

Berdasarkan table 4.3 diatas terlihat bahwa "responden yang memiliki dukungan keluarga yang Baik berjumlah 11 orang (20,8\%)dan respoden yang memiliki dukungan keluarga yang kurang berjumlah 42 orang $(79,2 \%) "$.

Tabel 1.4 Distribusi Responden berdasarkan kunjungan ke posyandu

\begin{tabular}{|c|c|c|c|}
\hline No & $\begin{array}{c}\text { Kunjungan } \\
\text { Ibu Balita } \\
\text { Ke } \\
\text { Posyandu }\end{array}$ & Frekuensi & $\%$ \\
\hline 1 & Aktif & 25 & 47,2 \\
\hline \multirow[t]{2}{*}{2} & Tidak Aktif & 28 & 52,8 \\
\hline & Total & 53 & 100 \\
\hline
\end{tabular}

Berdasarkan table 4.4 diatas terlihat bahwa responden yang Aktif berkunjung ke posyandu berjumlah 25 orang $(47,2 \%)$, responden yang tidak aktif berkunjung ke posyandu 28 orang $(52,8 \%)$.

\section{Tabel 1.5}

\begin{tabular}{lcc}
\hline \multicolumn{1}{c}{$\begin{array}{c}\text { Variabel } \\
\text { Independen }\end{array}$} & $\begin{array}{c}\text { Koefisiensi } \\
\text { korelasi }\end{array}$ & $\begin{array}{c}\rho \\
\text { value }\end{array}$ \\
\hline $\begin{array}{l}\text { Pengetahuan/ } \\
\text { pendidikan ibu }\end{array}$ & 0,037 & 0,791 \\
\hline Motivasi ibu & 0,034 & 0.609 \\
\hline $\begin{array}{l}\text { Dukungan } \\
\text { keluarga }\end{array}$ & 0,076 & 0.590 \\
& &
\end{tabular}

Pada tabel 1.5 menggambarkan faktor-faktor yang berhubungan dengan kepatuhan kunjungan posyandu di desa mentuda kecamatan lingga diperoleh hasil sebagai berikut : pengetahuan atau pendidikan ibu dengan kepatuhan kunjungan posyandu didapatkan nilai $\mathrm{r}=0.037$ dengan $\rho$-value 0,791 yang lebih besar dari nilai alpha $(<0,05)$. Kesimpulan yang diperoleh dari hasil ini tidak ada korelasi yang signifikan antara pengetahuan/ pendidikan ibu 
dengan kepatuhan kunjungan

posyandu.

Untuk motivasi ibu didapatkan nilai $\mathrm{r}$

$=0,034$ dengan $\rho$-value 0,609 yang lebih besar dari nilai alpha $(<0,05)$. Kesimpulan yang diperoleh dari hasil ini tidak ada korelasi yang signifikan antara motivasi ibu dengan kepatuhan kunjungan posyandu.

Untuk dukungan keluarga "didapatkan nilai $\mathrm{r}=0,076$ dengan $\rho$ value 0,590 yang lebih besar dari nilai alpha $(<0,05)$. Kesimpulan yang diperoleh dari hasil ini tidak ada korelasi yang signifikan antara dukungan keluarga dengan kepatuhan kunjungan posyandu".

\section{PEMBAHASAN}

Hubungan pengetahuan dengan kepatuhan kunjungan ibu balita ke posyandu dapat dilihat "pada tabel 4.5 yang berdasarkan hasil penelitian yang menggunakan Uji Spearman Rho menunjukkan adanya tidak ada hubungan yang bermakna antara pengetahuan dengan kepatuhan kunjungan ibu balita ke posyandu, dengan nilai $\mathrm{p}$ value sebesar $0,791 "$.

Hal ini menunjukkan bahwa $\mathrm{p}$ value lebih besar dari nilai alpha tabel Uji Spearman Rho $(5,991)$ dengan level of significance $(0,05)$. Dalam penelitian ini responden yang digunakan adalah ibu balita yang ada di Desa Mentuda Kecamatan Lingga Kabupaten Lingga.

Berdasarkan penelitian yang telah dilakukan peneliti, dari "hasil pembagain kuesioner dan wawancara kepada responden. Berdasarkan hasil ini dapat diasumsikan bahwa semakin kurang pengetahuan ibu tentang posyandu maka semakin banyak ibu yang tidak membawa balitanya ke posyandu. Di sebabkan karena 
jika ibu mengetahui manfaat posyandu dan pelayanan yang dilakukan posyandu maka balitanya akan di bawa terus-menerus ke posyandu untuk melihat perkembangan dan kesehatan balitanya, maka ibu dapat menilai dan berbuat sesuatu untuk memperbaiki dan meningkatkan kesehatan balitanya jika ibu mempunyai pengetahuan yang baik dan juga dapat merubah perilaku ibu kearah lebih baik".

Dari hasil yang dilakukan oleh Mulyani (2009), "Hubungan antara pengetahuan dengan kunjungan balita ke posyandu wilayah kerja Puskesmas Patuk Kabupaten Gunung Kidul, di ketahui ada tidak hubungan antara pengetahuan dengan kunjungan balita ke posyandu”.
Hal ini sesuai dengan teori (Notoatmodjo, 2007) "Tingkat pengetahuan seseorang banyak mempengaruhi perilaku individu, dimana semakin tinggi tingkat pengetahuan seorang ibu tentang manfaat posyandu, maka semakin tinggi pula tingkat kesadaran untuk berperan serta dalam program posyandu. Pengetahuan tentang posyandu yang rendah akan menyebabkan rendahnya tingkat kesadaran ibu yang memiliki balita untuk berkunjung ke posyandu. Pengetahuan dapat mengubah prilaku kearah yang di inginkan begitu juga dengan kunjungan ibu ke posyandu".

Hasil penelitian menyatakan bahwa rerata responden dalam penelitian ini yang berpengetahuan baik (30.2\%), walau secara proporsi antara yang berpengetahuan baik 
dan kurang (69.8\%), lebih tinggi yang berpengetahuan kurang untuk berperilaku kunjungan baik.

"Hubungan motivasi ibu dengan kunjungan ibu balita ke posyandu dapat dilihat pada tabel 4.6 yang berdasarkan hasil penelitian yang menggunakan uji Uji Spearman Rho menunjukkan adanya tidak ada hubungan yang bermakna antara motivasi ibu dengan kepatuhan kunjungan ibu ke posyandu, dengan nilai $\mathrm{p}$ value sebesar 0,609 . Hal ini menunjukkan bahwa $\mathrm{p}$ velue lebih besar dari dari nilai alpha $(<0,05)$ ". Motivasi diartikan sebagai "suatu kekuatan yang terdapat dalam diri organisme yang menyebabkan organisme itu bertindak atau berbuat, dorongan itu tertuju pada suatu tujuan tertentu. Namun demikian ada pula perbuatan yang tidak didorong oleh motif, namun perbuatan itu berlangsung secara otomatis" (Ahmadi, A, 2009). Proporsi responden yang memiliki motivasi baik (26.4\%) lebih kecil dibandingkan proporsi responden yang memiliki motivasi kurang $(73.6 \%)$.

Hal ini sesuai dengan penelitian Yurianti (2010) menyebutkan bahwa "ada hubungan yang bermakna antara motivasi ibu dengan kepatuhan kunjungan ibu balita ke posyandu".

Hubungan dukungan keluarga dengan kunjungan ibu balita ke posyandu dapat dilihat "pada tabel 4.7 yang berdasarkan hasil penelitian yang menggunakan uji Uji Spearman Rho menunjukkan tidak adanya hubungan yang bermakna antara dukungan keluarga dengan kepatuhan kunjungan ibu ke posyandu, dengan 
nilai $\mathrm{p}$ value sebesar 0,590 . Hal ini

menunjukkan bahwa $\mathrm{p}$ velue lebih

besar dari nilai alpha $(<0,05)$ ”.

Green (1980) “mengemukakan

salah satu faktor penguat yang

mendukung perilaku mempeoleh

tindakan kesehatan atau tidak

adalah keluarga".

Yurianti (2010) dalam

penelitiannya mengatakan

"responden yang mendapat

dukungan dari keluarga untuk

membawa balita ke posyandu pada

umumnya adalah suami meskipun

ada beberapa yang mendapat

dukungan dari orang tua atau

mertua".

Dari hasil analisis diketahui bahwa

proporsi responden yang mendapat

dukungan dan mempunyai perilaku

kunjungan ibu balita ke posyandu

baik sebesar (20.8\%) jauh lebih rendah dari dukungan keluarga kurang (79.2\%).

Hasil penelitian ini sama dengan penelitian Yurianti (2010) bahwa "ada hubungan bermakna antara dukungan keluarga dengan kepatuhan kunjungan ibu balita ke posyandu".

Hal ini berbeda dengan penelitian Hestri Suryaningsih (2012), bahwa tidak bermakna atau tidak ada hubungan antara dukungan keluarga dengan kepatuhan kunjungan ibu balita ke posyandu.

\section{KESIMPULAN}

1. Diketahui gambaran kepatuhan kunjungan posyandu sebagian besar tidak aktif berkunjung ke posyandu 28 responden $(52,8 \%)$

2. Diketahui sebagian besar ibu 69,8 $\%$ memeliki pengetahuan/ pendidikan kurang. Lebih dari sebagian Ibu dengan motivasi keluarga yang kurang yaitu 
$73,6 \%$, Lebih dari sebagian

responden $\quad 79,2 \% \quad$ memiliki

dukungan keluarga yang kurang.

3. Diketahui "faktor-faktor yang berhubungan dengan pengetahuan atau pendidikan ibu dengan kepatuhan kunjungan posyandu didapatkan nilai $\mathrm{r}=0.037$ dengan $\rho$-value 0,791 yang lebih besar dari nilai alpha $(<0,05)$. Kesimpulan yang diperoleh dari hasil ini tidak ada korelasi yang signifikan antara pengetahuan/ pendidikan ibu dengan kepatuhan kunjungan posyandu".

Untuk motivasi ibu didapatkan nilai $r=0,034$ dengan $\rho$-value 0,609 yang lebih besar dari nilai alpha $\quad(<0,05)$. Kesimpulan yang diperoleh dari hasil ini tidak ada korelasi yang signifikan antara motivasi ibu dengan kepatuhan kunjungan posyandu.

Untuk dukungan keluarga didapatkan "nilai $\mathrm{r}=0,076$ dengan $\rho$-value 0,590 yang lebih besar dari nilai alpha $(<0,05)$. Kesimpulan yang diperoleh dari hasil ini tidak ada korelasi yang signifikan antara dukungan keluarga dengan kepatuhan kunjungan posyandu".

\section{SARAN}

1. Ibu balita

Ibu merupakan orang pertama yang selalu menjaga kesehatan anaknya, sebaiknya ibu harus selalu memeriksa pertumbuhan dan perkembangan anaknya ke posyandu karena jika ada penyakit bisa terdeteksi.

2. Bagi Mahasiswa/i 
Diharapkan ada penelitian lebih lanjut tentang faktor - faktor lain dan variabel - variabel yang berhubungan dengan posyandu sehingga dapat memperluas pengetahuan mahasiswa/I dalam penelitian yang serupa.

3. Bagi dinas kesehatan

Dari hasil penelitian ini, pencapaian kunjungan ibu masih jauh dibawah target dinas kesehatan untuk itu perlu peningkatkan dalam melaksanakan sosialisasi dan penyuluhan kepada ibu balita dan juga perlu "memperhatikan sarana dan prasarana kesehatan di posyandu seperti : posterposter, buku, leafleat yang berhubungan dengan posyandu dan alat-alat mainan edukatif sehingga diharapka bisa merangsang anak-anak untuk mau datang dan ditimbang ke posyandu”.

\section{Bagi Puskesmas}

Diharapkan bisa meningkatkan cakupan D/S antara lain dengan cara :

a. "Puskesmas secara berkala melakukan refressing kader guna meningkatkan pengetahuan kader dan memberikan reward kepada kader yang aktif sehingga bisa menjadi motivasi kader untuk lebih aktif”.

b. "Pengantian buku KIA/KMS bagi balita yang tidak punya Karena rusak atau hilang”.

5. Bagi Peneliti lain

a. "Perlu dilakukan penelitian lebih lanjut menggunakan variabel yang belum dilakukan dalam penelitian ini sehingga bisa diperolah 
informasi yang lebih dalam

tentang faktor-faktor yang

berhubungan denga

kepatuhan kunjungan ibu

balita ke posyandu".

b. "Peneliti yang ingin meneliti dengan topik yang sama

diharapkan dalam pemilihan

desain penelitian bisa lebih

baik, seperti studi kohort”.

c. "Pengembangan kuesioner yang lebih baik dengan pertanyaan-pertanyaan yang lebih detail untuk variabel yang penting terkait dengan kepatuhan kunjungan misalnya pentingnya dukungan keluarga”.

\section{DAFTAR PUSTAKA}

Amalia, Endra. (2018). Faktor Mempenagruhi Kunjugan Ibu Membawa Balita ke Posyandu Kelurahan Tanjung Pauh. STIKes Perintis Padang.
Arikunto, Suharsimi. (2016). Prosedur Penelitian Suatu Pendekatan Praktik, Jakarta : PT Renika Cipta Efendy, Nasrun. (2013). Dasar-dasar Perawatan Kesehatan Masyarakat. Jakarta : EGC.

Fitriani, Susi. (2012). Factor-faktor yang Mempengaruhi Kunjugan Ibu Balita ke Posyandu Teratai Kelurahan Puhun Tembok Wilayah Kerja Puskesmas Plus Mandiangin.Jurnal Kesehatan Masyarakat Stikes Prima Nusantara Bukittinggi.

Idaningsih, Ayu. (2016). Faktor-Faktor yang Berhubungan dengan Kunjungan Balita ke Posyandu. STIKes YPIB Majalengka.

Kementrian Kesehatan RI. (2016) Pedoman Umum Pengelolaan Posyandu. Jakarta: Kementrian Kesehatan RI.

Laila, S. N. E. Al. (2011). Hubungan Pengetahuan Ibu Balita Dengan Kepatuhan Kunjungan Balita Ke Posyandu Di Desa Sumberejo Kecamatan Mraggen Kabupaten Demak. Jurnal Kesehatan, 39-44. Retrieved from https://jurnal.unimus.ac.id/index.php/ jur_bid/article/view/818Singarimbu n, Masri dan Effendi, Sofian. 
(1995). Metode Penelitian Survai, Jakarta : LP3ES

Malahayati. (2013). Faktor-Faktor yang Berhubungan dengan Kunjungan Ibu Balita ke Posyandu Tersanjung di Desa Leng Keubeu Kabupaten Nagan Raya. Skripsi Sarjana Kesehatan Masyarakat. Universitas Teuku Umar.

Maria, Hetty. (2017). Faktor Penyebab Penurunan Kunjungan Bayi di Posyandu Puskesmas Langsat Pekanbaru. AKBID Sempena Negeri Pekanbaru.

Pamungkas, Lia. (2008). Hubungan antara Faktor Pengetahuan, Sikap dan Kepercayaan dengan Perilaku Ibu Berkunjung ke Posyandu III Kelurahan Grabag Kecamatan Grabag Kabupaten Magelang.

Pradana, Adi Puspa. (2016). FaktorFaktor yang Mempengaruhi Kepatuhan Kunjungan Ulang Ibu Balita Pneumonia Usia 2 bulan tahun di Wilayah Kerja Puskesmas Gubug I Kabupaten Grobogan. Skripsi Sarjana Kesehatan Masyarakat. Universitas Negeri Semarang.
Sakbaniyah, Lailia. (2012). Hubungan Pengetahuan Ibu Balita dengan Kepatuhan Kunjungan Balita ke Posyandu di Desa Sumberejo Kecamatan Mranggen Kabupaten Demak. Studi DIII Kebidanan Universitas Muhammadiyah Semarang.

Seksi Pomkes Dinkes Lingga. (2011). Buku Panduan Kader Posyandu. Dinkes Lingga.

Sugiyono. (2014). Statistika Untuk Penelitian, Bandung : Alfabeta.

Surya, Hestri. (2012). Faktor-faktor Yang Berhubungan Dengan Perilaku kunjungan Ibu Bayi Dan Balita ke Posyandu di Puskesmas Kemiri Muka Kota Depok. Skripsi Sarjana Kesehatan Masyarakat Peminatan Kebidanan Komunitas. Universitas Indonesia. Tricia Y, (2008). Faktor-faktor yang Berhubungan dengan Tindakan Ibu untuk Membawa anak balitanya ke posyandu di Kecamatan Palas Kabupaten Lampung Selatan Tahun 2008. Skripsi: Program Sarjana Kesehatan Masyarakat, Universitas Indonesia. 
Yuryanti. (2010). Faktor-faktor

yang berhubungan denga

perilaku kunjungan ibu balita di

posyandu di Kelurahan Muka

Kuning Wilayah kerja

Puskesmas Sei Pancur Kota

Batam tahun 2010. Skripsi:

Program Sarjana Kesehatan

Masyarakat, Universitas

Indonesia. 